\title{
Issues of Rice Policy in the Lower Mekong Basin
}

\author{
Rob Cramb
}

The commercialisation of rice farming in the Lower Mekong Basin has been at the centre of that region's remarkable journey out of poverty and food insecurity since the 1970s. Given that rice has long been the staple food in the region and that most of the population were rice growers, a development strategy that centred on opening up rice farming to productivity-enhancing investments had the double effect of increasing the incomes of large numbers of poor rural households while generating a marketable surplus to supply the rapidly growing urban population (and rice-deficit rural areas). The growth in export demand from elsewhere in Asia further added to the incomes of rice farmers in the more productive parts of the Basin (Northeast Thailand and the Delta), while initially providing a source of tax revenues and foreign exchange to support industrialisation strategies. Thus, a development pathway emerged that was driven by political necessity to be broadly based and inclusive, regardless of the nature of the political regime (Timmer 2008).

R. Cramb $(\square)$

School of Agriculture and Food Sciences, University of Queensland, St Lucia, QLD, Australia

e-mail: r.cramb@uq.edu.au

(C) The Author(s) 2020

R. Cramb (ed.), White Gold: The Commercialisation of Rice

Farming in the Lower Mekong Basin, https://doi.org/10.1007/978-981-15-0998-8_21 
However, the very success of this pathway and the economic growth it has helped generate have created new policy issues and dilemmas, requiring adjustments in the long-term emphasis on the intensification of smallholder rice production. Most obviously, the rapid growth in production has contributed to a secular decline in market prices, particularly for bulk grades of rice, while the costs of fertilisers, fuel, and labour have been increasing, creating a classic cost-price squeeze on farmers' incomes. While a lower price of rice has been a major factor in reducing both urban and rural poverty (Warr 2015), it has led to pressure from surplusproducing farmers for price support, putting them at odds with downstream actors in the value chain and creating dilemmas for economic planners and policy makers. The volatility of export prices in what has always been a thin market but one which is increasingly interlinked with other global food and energy markets has added to the difficulty of managing domestic supplies to maintain low and stable prices for consumers.

These policy dilemmas are linked with an array of other issues, including the persistence of smallholdings in the face of a perceived need for larger production units to achieve new technical and marketing efficiencies; the growing preference of many rice farmers for more flexible and diversified farming systems, counter to long-standing rice intensification policies; and the role of state-owned and private enterprises in the processing and exporting sectors. These issues have arisen in the broader context of a changing physical environment - resulting from both hydropower development along the river and global climate change-that is creating particular challenges for rice production in the Basin (Friend et al. 2019). All of these developments raise questions about future investment in the research system that gave rise to the productive technologies underpinning the transformation of rice farming in the Basin.

This chapter briefly explores some of these policy issues and dilemmas using the categories in Chap. 1, Fig. 1.9-policies influencing access to resources (specifically, to land, water, and technology), the management of farm activities (whether specialised in production of high-quality rice or diversified into production of non-rice crops), and the appropriation of value (as determined by interventions in the marketing and pricing of paddy and rice). 


\section{ACCESS}

\section{The Scale Issue in Rice Farming}

As outlined in Chap. 1 , the commercialisation of rice farming in the Lower Mekong Basin has occurred in the context of (and has contributed to) economy-wide structural transformation that, notwithstanding sustained agricultural growth, has seen agriculture's share of national income and employment decline, following the general pattern of agrarian transition with economic development (Cramb and Newby 2015; Mellor 2017). Relatedly, there has been a dramatic fall in fertility and a slowing of population growth throughout the Basin. While agricultural employment continues to grow in most parts of the Basin, the rate of growth has significantly slowed; in Thailand, the absolute size of the agricultural workforce has been in decline since around 1990, including in the Northeast (Grandstaff et al. 2008). The slower growth in the total labour force, the movement of labour out of agriculture, and the ageing of the farm workforce have increased the demand for mechanisation in rice farming, as seen in all parts of the Basin, including Laos and Cambodia. This began everywhere with small, farmer-owned machines-two-wheeled tractors and portable pumps-but in Northeast Thailand, it has already evolved into mediumscale mechanisation with four-wheeled tractors and combine harvesters operated largely by contractors. Combine harvesters are also now widespread in the Delta and becoming more common in Cambodia and Laos.

The exodus of labour and the availability of mechanical technology might be expected to lead to an increase in average farm size, as commercial farmers with access to capital buy up the holdings of those who leave farming, following the historical pattern of the developed countries (Paarlberg and Paarlberg 2000; Rigg et al. 2016). Yet, as Rigg et al. (2016) have highlighted, smallholder farming has persisted in the Lower Mekong countries and elsewhere in Southeast Asia, especially in wet rice farming. In the Vietnamese Delta farm size averages 1.2 ha, but $38 \%$ of holdings are under 0.5 ha and there is a significant cohort of landless households. Even in Thailand, where rapid industrialisation began in the 1980s and the agrarian transition is most advanced, average farm size continued to decline into the 2000 s, though it remained stable at 3.2 ha between the 2003 and 2013 agricultural censuses.

Rigg et al. (2016) point out some cogent reasons for this apparent lack of a trend to farm amalgamation, notably the "sheer competitiveness of 
small family farms, especially in rice-based systems" (p. 124); the microscale of mechanisation, well adapted to rice smallholdings, together with the emergence of contractors who can make the services of larger machines widely available; and the nature of rural livelihoods, such that many or most rural households have some members working in the urban sector while other, usually older members are able to maintain small rice farms that on their own would be "sub-livelihood." Cramb and Newby (2015) also emphasise the vital role of the traditional wet-season rice crop in underpinning the subsistence of even highly commercialised and diversified farm households in Laos and Cambodia. Additional reasons mentioned by Rigg et al. (2016) for holding on to small farms are the long-term social and economic value placed on land as an asset and the security it is perceived to provide in the face of the precariousness of much non-farm employment.

Rigg et al. (2016) also argue that the political economy of rice farming is such that government policy has in recent decades swung around from taxing to protecting rice smallholders, enabling them to persist longer than would be the case if technical and economic forces prevailed (see Chap. 2). The ill-fated rice-pledging scheme in Thailand is cited as evidence. However, this form of subsidy was clearly unsustainable and well in excess of the level of protection afforded by most governments in the Basin (Tobias et al. 2012). In any case, input and output subsidies are notoriously regressive, being appropriated mostly by larger farmers, increasing the incentive for them to expand their holdings (Poapongsakorn 2010).

Regardless of these arguments, it seems that governments are in fact increasingly concerned about the persistence of small rice farms and are looking for ways to encourage larger and more efficient operational units, though without upsetting the prevailing ownership structure. The motivation is to increase both the quantity and quality of output through greater technical control over farming operations, thereby also enhancing farmers' persistently low incomes. This is being sought through local coordination to amalgamate adjacent paddies into larger fields more suited to mechanical operations, including realignment and land levelling.

In Northeast Thailand and Laos, such amalgamation of paddy fields is partly driven by contractors providing the services of four-wheeled tractors and combine harvesters who are seeking greater field efficiencies. Farmers can also benefit through land levelling that makes for more effective irrigation and stabilisation of yields. A long-term study of a typical 
rice-growing village along the Chi River in Khon Kaen Province in Northeast Thailand found that while the total paddy area had hardly changed between 1981 and 2005 and average farm size had declined to 1.4 ha, the number of separate plots had been reduced by a factor of three (from 8401 to 2885 ) and the average size of plot had accordingly increased three times (from 663 to $1983 \mathrm{~m}^{2}$ ) (Watanabe 2017). This dramatic consolidation of plots had proceeded with no government support. The beginnings of such a trend can be seen in some intensive rice-growing areas in Laos, with encouragement from local officials.

Notwithstanding these spontaneous developments, the military government in Thailand from 2014 to 2019 made "increasing efforts to tackle inefficiencies within small-plot farming" (FAO 2018: 6). The Agricultural Development Plan (2017-2021) includes a "Large Fields Scheme" or "area-based extension approach," intended to reduce production costs and increase farmers' returns. The approach involves consolidating many small paddy fields into a large farm while the ownership remains unchanged, setting up a farmers' organisation of the participating landholders, and appointing a farm manager for the enlarged farm. The Plan argues that this will facilitate site-specific government extension and support, economies of scale in production, and increased bargaining power for farmers (Pongsrihadulchai 2018).

In the longer term in Thailand, it is likely that, even in the absence of government intervention, the economic pressures for ageing smaller farmers to sell to larger entrepreneurial farmers will eventually prevail and the proportion of paddy land held in large holdings will increase over the coming decades, causing not only the size of paddies but the average farm size to gradually rise. In this context, Timmer (2015: 99) quotes Nipon Poapangsakorn of the Thailand Development Research Institute, who writes: "I think it is likely that the paddy farm size will easily reach 200500 ha in the next ten years because the technology is there for a farm entrepreneur to manage such farm size."

In the Vietnamese Delta, with over a third of households having less than 0.5 ha of rice land, the scope for spontaneous land consolidation is much more limited. Rather, since 2010, the government has been encouraging a "Small Field, Large Farm" model to be coordinated by large agribusinesses such as the An Giang Plant Protection Company (now the Loc Troi Group) in a form of contract farming, encompassing as much as $10 \%$ of the paddy area in some provinces (Nguyen and Dao 2018). ${ }^{1}$ In addition, a law issued in 2013 allows the accumulation of annual cropland 
(including paddy land) in the Delta to a maximum of 30 ha, specifically to encourage a more efficient and profitable scale of farming (Nguyen et al. 2017). Given the ongoing net outmigration from the Delta, farm size may soon begin to rise, even in this most densely populated part of the Basin.

As seen in Chap. 12, the land situation in southern Cambodia is similar to that in the Delta, with small farms and few plots per farm, these plots a result of land allocation in the 1980s to give households a share of different land types. Hence, spontaneous plot amalgamation is likely to be difficult. However, a similar contract-farming approach to that promoted in Vietnam has been tried here, as reported in Chap. 16. There are also some recent examples in Laos involving contracts between farmer cooperatives and rice milling companies. ${ }^{2}$ Experience so far with this model is mixed as it requires an accumulation of trust between the parties and adequate capital on the part of the contractor, but there is likely to be continued policy emphasis in all jurisdictions on finding ways to manage small, independent landholdings to obtain the perceived benefits of larger operations.

\section{River Management, Irrigation Schemes, and the Small-Pump Revolution}

The Lower Mekong Basin is a vast catchment that is not only a productive rice bowl, producing a quarter of the world's rice exports, but also the world's largest inland fishery and a major source of hydroelectricity, powering the region's industrialisation. The trade-offs between these three functions of the river system are, however, becoming increasingly apparent, accentuated by climate variability and change, raising new issues for rice policy. Cosslett and Cosslett (2018: 111) identify three environmental factors having a major long-term impact on rice production in the Basin: "one, climate change and the outlook for global warming and associated sea level increases; two, El Nino and La Nina events that have been shown to be causative factors in some of the severe flood/drought weather cycles; and three, the construction and operation of China's mainstream dams on the Lancang River that have changed water flow regimes in downstream countries." Of these three factors, they consider that "the construction of dams on the Mekong River appears to pose the most imminent threat to both the near-term and the long-term sustainability of rice production in the Lower Mekong Basin" (Cosslett and Cosslett 2018: 111).

Of course, numerous hydropower dam projects have also been constructed along the tributaries of the Lower Mekong Basin itself, with at 
least 100 projects forecast for Laos by 2020 and new developments underway in Northeast Cambodia (IFC 2017). Moreover, eleven large dams are planned for the main river in the Lower Basin, nine of them in Laos (Blake and Barney 2018); the controversial Xayaburi Dam on the main river within Laos is due to be operational in 2019. However, the total storage volume in all dams within Laos is estimated to be less than one-tenth the storage capacity of the Lancang cascade in China. ${ }^{3}$

The cumulative impact of all these dams on rice farming includes reduced delivery of upstream sediments and altered flow regimes (MRC 2017; IFC 2017; Hecht et al. 2019). ${ }^{4}$ While the reduction in sediments is detrimental to the annual renewal of the Mekong floodplain and is likely contributing to the net erosion of the Delta since 2005, the general impact on flows has been mixed, with reduced flows (and flooding) in the wet season and increased flows in the dry season. The reduced wet-season flows may limit irrigation in that season (especially in drought years such as 2019), while the increased dry-season flows, though limiting the extent of traditional river-bank gardens, may increase the potential for pump irrigation from both streams and groundwater (Hecht et al. 2019). The reduced extent of flooding is of course beneficial for wet-season rice in flood-prone areas of the Khorat Plateau, but reduces the potential for flood-recession rice in the Tonle Sap Basin and the Delta. ${ }^{5}$ The moderating effects of run-of-the-river dams can be contrasted with the effect of diversion schemes such as the Nam Theun 2 Dam in Laos, which can substantially reduce flows in one catchment while increasing the incidence of flooding in another (Blake and Barney 2018; Hecht et al. 2019).

Large-scale irrigation works, enabling farmers to supplement rainfall in the wet season and extend rice cultivation into the dry season, have also been implemented in the Lower Mekong Basin since Angkorean times, usually with more positive impacts on rice cultivation. Major public investments in irrigation schemes occurred up to the 1990s, especially in Northeast Thailand and Laos (Hoanh et al. 2009). These were seen as an essential complement to the high-yielding seed-fertiliser technologies, which had been the experience in the earlier phase of the Green Revolution in Thailand's central plain, as well as in Indonesia and the Philippines. Yet, as Hoanh et al. (2009: 149) observe, "despite the great achievement in rice production in the LMB countries, there is a general consensus that irrigation systems have not lived up to expectations because of low performance in terms of control, water productivity, yields and quality of service delivery to farmers." Blake and Barney (2018) make similar observations 
specifically for Laos, particularly for schemes that are merely adjuncts to hydropower projects. Noble and Hoanh (n.d.: 7) conclude that "the provision of irrigation infrastructure has not proved to be a panacea." Notwithstanding this consensus, the further "greening of Isan" is still apparently a policy aspiration in Thailand, particularly under the military government (Molle et al. 2009; Blake 2019), and increased investment in irrigation is also espoused in Laos and Cambodia, though in practice the focus there is now more on rehabilitating, maintaining, and achieving fuller utilisation of existing irrigation works for dry-season rice production. ${ }^{6}$

Hence rainfed, wet-season rice farming remains the dominant production system in the Basin in terms of area, except in the Delta. Here there has been a much longer-term project of hydraulic engineering to achieve water control through dikes, canals, and irrigation works. This has proved critical to the expansion of double and triple cropping of rice in the central corridor of the Delta, utilising both tidal and pump irrigation systems (the latter accounting for $26 \%$ of the irrigated area). The rapid adoption of small, portable pumps has given farmers much greater flexibility in accessing and utilising this irrigation infrastructure, enabling a boost in dryseason cropping and increasing crop diversification, as described in Chap. 17. Yet as Biggs et al. (2009: 203) observe, "this made landscape, defined by ongoing canal-building enterprises and other works associated with a rapidly urbanizing human landscape, remains at constant risk of being unmade by the destructive and sediment-spreading natural effects of seasonal floods, erosion from daily tidal fluxes, storms and also the manmade effects from poorly placed dikes and other works." They add that "the nature of waterscape transformations is such that the state eventually has to cope with the maintenance of this hydro-agricultural 'machine'...," something they note that French engineers in the early twentieth century worried would become "a work without end" (Biggs et al. 2009: 216). They conclude that "...the financial implications of the need to maintain and protect the 'delta machine' are awesome..." (Biggs et al. 2009: 222). This "work without end" is being exacerbated by the growing threat of salinity and sea-level rise. In 2016, climate change combined with an El Nino drought resulted in the worst recorded salinity intrusion in the Delta, extending over $80 \mathrm{~km}$ inland and destroying at least 160,000 ha of crops. Chapman and Van (2018) report accelerated outmigration in those provinces worst affected by climate change and salinity.

While work continues on existing irrigation infrastructure throughout the Basin, in many ways a more significant trend has been the emergence 
of self-managed, on-farm irrigation through the construction of small ponds and shallow tube wells accessing groundwater, in both cases using the ubiquitous small-scale pumps. As noted in Chap. 2, digging of farm ponds adjacent to paddy fields began to take off in Northeast Thailand in the 1990s. This was a private initiative, subsequently supported through a revolving loan fund from the mid-2000s (Rambo 2017). The ponds took some land out of production but helped stabilise rice yields through supplementary irrigation in the wet season and permitted small-scale utilisation of paddy fields for non-rice crops (vegetables and field crops) in the dry season, as well as supporting the rearing of fish and livestock (Promkhambut and Rambo 2017). Farm ponds are also beginning to be recognised as a resource in the rainfed lowlands of Cambodia and Laos (Vote et al. 2019).

In addition, there has been a rapid increase in the private installation of tube wells in paddy fields, drawing on shallow alluvial aquifers in the Mekong lowlands (Johnston et al. 2013). For example, in Prey Veng Province in the south of Cambodia, the number of tube wells used for irrigation increased from 1600 in 1996 to 25,000 by 2005 . The case studies in Chap. 13 show how on-farm irrigation enabled small-scale farmers to augment wet-season rice with an early wet-season rice crop and up to two short-term dry-season cash crops such as radish. While groundwater is available in most of the Tonle Sap Basin, "its sustainability as a resource is unclear" and "promoting extensive groundwater use before the resource is better defined is not recommended" (Johnston et al. 2013: 5-6). Nevertheless, the experience elsewhere in Asia suggests that farmers will continue to exploit this resource, even more so as rural electrification brings down the cost of pumping (Molle et al. 2003). Moreover, the independent control this gives farmers over water management will further underscore the trend to farm diversification discussed below, given the higher returns to irrigating non-rice crops. Nevertheless, research in Laos indicates that, even where sourcing groundwater for cropping is demonstrated to be technically feasible, dry-season production may be limited by the increasing cost of labour and energy (Clément et al. 2018).

\section{Access to Biological and Mechanical Technology}

Public investments in research and rural infrastructure (roads, canals, irrigation) were critical in giving smallholder rice farmers access to the improved varieties and complementary inputs, especially water and 
fertilisers, which have underpinned the growth in yields, output, and marketable surplus. The Green Revolution in the Lower Mekong came later and was more adaptive than the earlier input-intensive, high-yield package, based initially on IR8, which was implemented elsewhere in Asia. Long-term programmes of research and development were embedded in national institutions, enabling the selection, breeding, and dissemination of varieties that were suited to the preferences and circumstances of local farmers (Chap. 6). This can be seen in the impact of improved varieties of glutinous rice in Northeast Thailand and Laos, and of moderate-yielding but high-value local selections in Northeast Thailand and Cambodia. While IR8 and its high-input, high-yielding successors formed the basis of commercial growth in the Delta, here too policy is now favouring a shift to high-quality, high-value rice produced with less-intensive use of inputs.

Continuing collaborative research across the region has greater scope than ever to develop varieties adapted to local constraints of soil, pests, flood, drought, and salinity, partly a function of the altered hydrology of the river basin and of global climate change. Marker-assisted selection technology has incorporated pest and disease resistance in existing highquality varieties such as KDML105, helping to stabilise yields.? Incorporating genes for drought and submergence tolerance will assist varietal development in Laos. For these farmers, the provision of more resilient wet-season varieties will continue to be a priority, underwriting diversification into dryland crops such as cassava, sugarcane, and rubber. In the Delta, breeders are using marker-assisted selection and crosses with wild rice to develop varieties more tolerant of salinity, submergence, acidity, drought, and heat (Bui and Nguyen 2017). These improved varieties will provide increased resilience not only for specialised, commercial rice producers but also for those farmers in the marginal rainfed lowlands, for whom the single wet-season crop is still an essential component of their more diversified livelihoods. Policies to develop improved seed systems will be important to enable farmers to capitalise on the continuing gains made by crop breeders (Chap. 8).

The small-scale mechanisation (especially pumps, tractors, and combine harvesters) that has evolved in response to the increasing scarcity and cost of farm labour has not required policy intervention, other than providing a favourable environment for commercial innovation and distribution. This development of mechanical technology is complementing the gains made through biological technology by enabling rural households to remain in rice production while diverting labour to more remunerative 
non-rice and non-farm pursuits, thus improving rural livelihoods. As discussed above, these technologies are creating economies of scale in rice production, favouring larger fields and, in the long term, larger farms.

\section{Activities}

\section{Diversification of Rice-Based Farming Systems}

The structural transformation of the Mekong economies discussed above is also having an impact on the domestic demand for rice and hence the profitability of conventional rice production. As urban and rural incomes rise, the importance of rice in the diet declines and the demand for fruit, vegetables, and meat increases (Timmer 2015). As noted in Chap. 1, Table 1.2, rice consumption per capita has declined markedly in Thailand and is following a similar trend in Vietnam (Nguyen 2013). More telling is that the share of rice in the per-capita consumption of calories in Vietnam declined from $61 \%$ in 1993 to $13 \%$ in 2014 for the urban population, and from $76 \%$ to $27 \%$ for the rural population (Nguyen et al. 2017: 20). The nominal farm-gate price of paddy has stagnated during the 2010s in all Lower Mekong countries (Fig. 21.1), while the cost of inputs has continued to increase.

These trends in the domestic economy, combined with the long-term decline in the world rice price, have translated into the decreasing

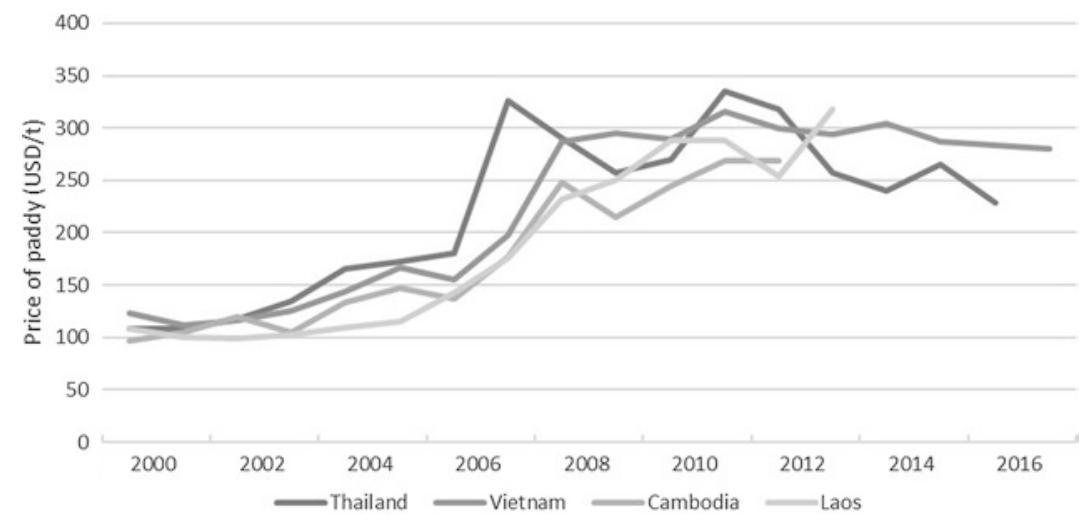

Fig. 21.1 Nominal farm-gate price of paddy in Lower Mekong Basin countries, 2000-2017 (USD/t). (Source: FAOSTAT) 
profitability of specialised rice production and the increasing relative profitability of non-rice crops, hence a strong preference of rice farmers to diversify into these crops. Structural shifts in consumer demand in neighbouring countries are also increasing the relative profitability of non-rice crops such as maize and bananas produced within the Basin for crossborder trade (mainly to China, Thailand, and Vietnam). The dilemma for governments, given their long-standing food security goals, is that they want to maintain the area of paddy land and encourage its maximal utilisation for rice production. In particular, their investments in water control have been predicated on the intensification of rice production and provide little flexibility for diversification. Yet coercing farmers to grow the now less-profitable rice is counter to the espoused goals of rural development. These tensions are being worked out in different ways in the four Lower Mekong countries.

In Northeast Thailand, there has been a confusing succession of policies, at first seemingly designed to further intensify rice production (notably through price support), then designed to wean farmers away from rice production, including discouraging dry-season rice in irrigated areas. As mentioned in Chap. 2, in 2016, the military government initiated a scheme that paid farmers subsidies to stop planting rice in areas deemed to be unsuitable and to develop integrated farming systems instead, with onfarm irrigation, fish, and livestock. Official maps appear to designate some of the most profitable areas for jasmine rice production in the southern part of the Khorat Plateau as unsuitable for rice growing (Sunsuk 2016). ${ }^{8}$ Yet markets continue to pay an ever-higher premium for this highly valued variety (Chap. 2, Fig. 2.4), offsetting the effect of lower yields, as shown in Chap. 3. Moreover, it would seem that farmers in the Northeast have already allocated land less suitable for rice to field crops such as cassava, sugarcane, and rubber.

In Laos, the current policy is to focus support on more productive areas, especially where irrigation schemes have been established along the main Mekong corridor, to ensure that these schemes are working effectively and that farmers have access to high-quality inputs (seed and fertilisers) and modern rice mills, capable of producing export-quality rice. The 2016 National Rice Policy proposes to prohibit the conversion of paddy land within these focal areas to other uses. At the other extreme, in the sloping uplands, government policy has long favoured the reallocation of land to non-rice crops such as maize, bananas, and rubber, both to eliminate shifting cultivation and increase farm incomes. However, the 
widespread leasing of land to Chinese investors for banana plantations in Northern Laos has extended to lowland paddy fields, prompting provincial authorities to ban this change in land use, though it is unclear whether this is to protect paddy land as such (including from pesticide pollution) or to assert official control over the banana boom.

In Cambodia, there are no land-use controls as such, with the availability of irrigation in the dry season being the key determinant of rice intensification. As outlined in Chap. 13, farmers in flood-recession areas are finding that dry-season cultivation of high-yielding varieties for export to Vietnam is a profitable option, whereas farmers in wet-season rice areas are more inclined to use the limited on-farm irrigation from ponds and tube wells to support more diversified dry-season cropping. Most farmers, of course, have neither of these options and rely more on non-farm sources of income to augment the rainfed wet-season rice crop.

In the Delta, ongoing investments in water control have enabled double and triple cropping of rice in formerly flood-prone areas, giving farmers in these districts little option but to specialise in rice (though fish farming within the canals and flooded paddies allows a degree of diversification, as described in Chap. 17). These rice-specialist districts have somewhat lower incomes and higher incidence of child malnutrition and poverty (Nguyen 2013). Cazzuffi et al. (2018), using panel data from 2008 to 2016 for the whole of Vietnam, found that households selling a higher proportion of the rice they produced did not have significantly higher income or food consumption than those selling less rice, though they accumulated more assets. At the same time, households earning a higher proportion of total income from rice had lower income and no significant difference in asset accumulation. These results suggest that, while increased selling of rice has improved the welfare of rice-producing households over time, it is diversification into non-rice and non-farm activities that is providing higher household incomes. Thus, even in the rice bowl of the central Delta, there has been a trend to rotating rice with non-rice crops (maize, soybean, sesame, vegetables, and flowers) and the establishment of permanent orchards of fruit trees on the natural levees and back swamps of the alluvial floodplain. The policy response so far has been to marginally reduce the paddy area designated exclusively for rice production-from 4.3 million ha in 2013 to 4.0 million ha in 2020 (Chap. 17). It is likely there will be increasing pressure to further relax land-use controls in the coming decade. 
Even with these trends towards diversification away from rice, it will be important for ongoing public investment in research to maintain productivity and sustainability of especially the wet-season rice crop, which continues to provide the platform for diversified livelihoods throughout much of the Basin (Cramb and Newby 2015).

\section{Specialisation in High-Value Rice Production}

In those areas best suited for intensive rice cultivation, whether due to natural conditions or established infrastructure, the alternative to increasing farm incomes through diversification is to pursue specialisation in higher-yielding, higher-value, lower-cost rice production. In this regard, Northeast Thailand has led the way. Historically, the Green Revolution in this region differed in important respects from the high-input, high-yield model seen elsewhere in Asia in the 1960s and 1970s. As described in Chap. 2, plant breeding delivered a well-adapted glutinous variety (RD6) to secure subsistence supplies and a high-value fragrant variety (KDML105) for sale to domestic and export markets. Within the Northeast, many farmers in the southern provinces specialised in jasmine rice for sale, thereby creating a regional demand for a marketable surplus of glutinous rice produced mainly in the northern provinces. Hence, two groups of farmers benefited from specialisation in high-value, though not necessarily high-yield production.

Whereas Thai jasmine rice attracts a significant premium in export markets, there is growing domestic and export demand from environmentaland health-conscious urban consumers for organic rice, as well as rice with special characteristics such as nutritious, coloured, and local or native rice (Pongsrihadulchai 2018). As noted above, the Agricultural Development Plan (2017-2021) differentiates between "suitable" and "unsuitable" paddy land, with the former to be the focus of efforts to increase the value and reduce the costs of rice production, particularly through conversion to organic rice, ${ }^{9}$ while in the latter areas farmers are offered incentives to change from rice to other activities (Pongsrihadulchai 2018). However, the official target for $60 \%$ of production to be organic by 2027 seems ambitious, driven as much by ideology as market analysis. The case studies in Ubon Ratchathani Province reported in Chap. 3 showed that the organic farming village obtained a somewhat higher average return to land but a much lower return to labour than the conventional farming villagein an increasingly labour-scarce economy. According to the SCB (Siam 
Commercial Bank) Economic Intelligence Centre (2017), “organic farming remains a tiny niche industry in Thailand... just $0.3 \%$ of the country's agricultural land is certified as organic... fewer than $0.2 \%$ of Thailand's farmers practise organic agriculture... [but] domestic consumption of organic foods is likely to grow." In 2017 the military government introduced a new scheme to promote organic rice. Farmers receive THB 9000 per rai (USD 1700 per ha) over three years if they sign up to the scheme, almost equal to the average cost of production as reported in Chap. 3, hence it is unlikely to have wide coverage.

Cambodia's push into export markets since 2010 has centred on the promotion of its own high-quality rice as "white gold." As described in Chap. 19, over a million tonnes of paddy are exported annually from Cambodia to Vietnam, $80 \%$ of which is soc paddy, comprising traditional Cambodian wet-season varieties that are preferred by domestic consumers in Vietnam because of their high quality and the minimal use of agrochemicals by Cambodian farmers, and only $20 \%$ of which is than nong paddy, the low-quality IR rice that is milled and re-exported as standard Vietnamese rice. The export-promotion campaign has sought to increase the production and local milling of Cambodian fragrant rice (phka malis) and dry-season fragrant varieties for export not just across the border to Vietnam and Thailand but to Europe and increasingly to other destinations (IFC 2015). As noted in Chap. 11, the more profitable Cambodian aromatic varieties, mainly grown in the western provinces, now account for $10 \%$ of the annual cultivated area and $30 \%$ of total production (World Bank 2015) and by 2018 milled rice exports, though below the government's target, had risen to well over 600,000 t from only 40,000 t in 2010. To capitalise on the export potential of high-quality Cambodian rice, some miller-exporters are contracting with groups of farmers to provide pure seed, appropriate inputs, and credit in an effort to secure an adequate volume to fill export contracts, as described in Chap. 16. Though there were many issues with this project, such as credit constraints and side-selling, farmers who had participated achieved on average 12-25\% higher gross margins. It is noteworthy that support for specialised, highquality production in Cambodia is mainly coming from the agribusiness sector rather than from government agencies as in Northeast Thailand.

Laos is also looking to increase returns to rice farmers by promoting high-value production systems, mainly for export to China. There is a small demand for organic glutinous and jasmine rice and, as in Cambodia, miller/exporter companies have initiated contract-farming schemes with 
farmer cooperatives to provide seed and organic fertiliser on credit and purchase the paddy at an agreed price, up to $50 \%$ above that for standard glutinous rice destined for the domestic market. However, it has been difficult to meet the required export standards and thus to fill agreed quotas. In any case, the overall impact on farm incomes is not likely to be widespread.

In the Delta, despite specialist rice farmers achieving the highest yields and cropping intensities in the Basin, profitability remains low. Nguyen (2013) found that rice farmers in An Giang Province in 2009-2010 averaged a profit over three seasons of VND 3.8 million (USD 1,012) per household which, assuming the average household size of 4.4 persons, translates to VND 316,250 per person per month-below the poverty line of VND 400,000. Hence, to escape poverty, most households derived a considerable portion of income from non-farm sources. Based on a 2012 decree, the government offers direct financial support of VND 500,000 per ha per year for farmers on specialised paddy land and VND 100,000 per ha per year for farmers on other paddy land (not including uplands), but this has been difficult to implement and monitor and in any case has only a small impact on household income (Nguyen 2013). Other support includes a reduced land tax, subsidised credit, subsidised seed, and exemption from irrigation fees. More strategically, policy makers see the need to shift from the low-quality, low-priced rice that has formed the basis of competitive rice exports in previous decades in order to increase the returns to specialist rice producers.

As well as shifting to high-value varieties, there is a growing emphasis on increasing the sustainability of production systems in the Delta, both to reduce costs and to improve quality-based competitiveness. The Ministry of Agriculture and Rural Development's “One Must Do, Five Reductions” (1M5R) campaign promotes increased use of quality seed together with reduced seed rate, fertiliser use, water use, insecticide use, and post-harvest losses. Agribusiness groups such as Loc Troi are aiming to establish a certified sustainable value chain, using Vietnam's Good Agricultural Practice (VietGAP) standard. However, according to Demont and Rutsaert (2017), there is limited demand for VietGAP-certified product, limiting the price incentive for farmers to comply. Moreover, the fragmented nature of the supply chain, with numerous small collectors as the first point of contact with farmers, makes monitoring of sustainable practices problematic. 


\section{ApPropriation}

While rice policy in the Lower Mekong Basin has embraced a raft of interventions affecting farmers' access to resources and their production activities, it is price policy that has been seen as critical to the political legitimacy and survival of Mekong governments, both in the socialist one-party states of Vietnam and Laos and the quasi-democratic states of Cambodia and Thailand. Price policy determines who appropriates the "white gold" derived from the Basin's increasingly productive paddy fields. All regimes have manoeuvred to juggle the interests of net producers of rice and net consumers, with downstream actors in the value chain (traders, millers, wholesalers, and exporters) and various government departments (agriculture, finance, commerce) also caught up in what is an essentially political process. According to Timmer (2013), there is a historically deep-seated political imperative for each state to maintain food price stability within its borders.

The perennial dilemma has been to keep farm-gate prices high enough so that commercial rice farming remains profitable and rural protest is contained, while keeping the price to consumers low enough to avoid economic hardship and urban unrest. An array of tools has been employed, including mandating a minimum farm-gate price, intervening to purchase, store, and sell paddy and rice at administered prices, retail price controls, and subsidised provision of rice to vulnerable groups, and controlling exports through licensing, floor prices, quotas, and bans. The use of these tools has varied between jurisdictions and over time, with the long-term pattern conforming to Anderson and Hayami's (2019) finding for East Asia that, with economic growth and structural transformation, developing countries switch from taxing to protecting agriculture, particularly rice production, responding to the declining importance of rice in gross domestic product (GDP), employment, and consumer expenditure and the growing political power of the farm lobby, which can be mollified at lower budgetary cost. The conundrum is that there is "an urban bias in poor countries when farmers are a majority of the population, and a rural bias when urban consumers are a majority of the population" (Timmer 2013: 85).

\section{Rice Price Policy in Thailand}

Ricks (2018) has analysed the evolution of rice price policy in Thailand from a political economy perspective. From the 1950s to the 1970s, the 
authoritarian nature of Thailand's government meant that rural interests did not influence rice price policies, which were aimed at benefiting urban consumers and exporters while generating government revenue and foreign exchange. The tax burden on rice farmers was equivalent to a quarter of the total value of rice production in 1960. However, from 1979 to 2000 , the voting system required individual politicians to develop local political networks, and rice millers and traders were in the best position to assist. Moreover, elected governments now had to placate increasingly vocal farmers. This led to measures to reduce the overall tax on rice farming and to support farmers and millers through early forms of the paddy purchasing programme (Chap. 2). However, Ricks (2018: 404) reports that $80 \%$ of the benefits of the programme went to millers, exporters, political parties, and bureaucrats, with only $20 \%$ going to farmers and farm leaders.

With the change to the voting system in the 1997 Constitution, major party politics with regional constituencies came to the fore. In 2001, Thaksin Shinawatra's Thai Rak Thai Party was swept to power on the basis of rural votes in the North and Northeast. A key policy was an enhanced form of the paddy pledging scheme, which was transformed from a pricesmoothing device (enabling farmers to avoid selling immediately after harvest at low prices) into a mechanism for substantial price support. Now, most of the benefits went to farmers; millers became dependent on subsidies and income from renting storage to the government, while exporters' margins were squeezed. The political upheaval in the mid-2000s had complex causes, but at one level, it was a conflict between urban middle-class interests, represented by the Yellow Shirts, and rural interests, particularly in the North and Northeast, represented by the Red Shirts.

The military coup in 2006 was followed by further political turmoil and the installation of a government led by the Democrat Party under Abhisit Vejjajiva from 2008 to 2011, with support from the Yellow Shirts. The Abhisit government replaced rice pledging with an economically more rational price insurance scheme, but large farmers, millers, and exporters lost out under this scheme and Red Shirt protests intensified, resulting in a bloody military crackdown, the reaction to which ultimately brought the Abhisit government down.

In 2011, the Pheu Thai Party under Yingluck Shinawatra was swept to power with Red Shirt support on the promise to restore paddy pledging. From 2011 to 2014 , the scheme offered paddy prices up to $50 \%$ above the market price, buying over half the paddy produced. As described in Chap. 
2 , this led to the accumulation of up to 18 million $t$ and the eventual collapse of the programme (Welcher 2017). The expectation of a rise in the export price, enabling disposal of the stocks at a profit, was undermined by India's emergence as an exporter. The Pheu Thai government was removed by a military coup in 2014 and replaced by the National Council for Peace and Order (NCPO), which governed until 2019.

In 2016, the military government discontinued the rice-pledging and income insurance programmes and began disposing of stocks at discount prices (Chuasuwan 2018). Instead, short-term measures were introduced to help finance on-farm storage of fragrant and glutinous paddy, make direct payments and offer debt relief to farmers adversely affected by drought, and offset the cost of commercial crop insurance (Welcher 2017) - measures that can be seen as concessions to farmers in the North and Northeast. As described in Chap. 2, the military government has also initiated policies offering direct financial incentives to reduce the area planted to rice and encourage organic and integrated farming systems. It remains to be seen what direction rice price policy will take under the post-NCPO regime.

The history of rice price policy in Thailand since the 1980s thus represents a variant of Anderson and Hayami's (2019) transition from a large, voiceless agricultural sector that is exploited by government policy to a small but influential sector that can be protected at low political cost and low cost to the budget. In the past two decades, rice farmers in the North and Northeast have formed a sizeable and politically crucial bloc that became wedded to a programme of price support offered by an agrarian populist government, ${ }^{10}$ the implementation of which proved politically and financially unsustainable - though it took an alliance between the military and the urban middle class to bring the programme to an end.

\section{Rice Price Policy in Vietnam}

In Vietnam, "the combination of a strong, centralized bureaucracy and a single-party system has resulted in a relatively stable political environment" (Nguyen and Talbot 2014: 322) compared with that in Thailand. Nevertheless, rice price policy continues to be an important focus for the government. Support for rice producers remains central to the country's socialist programme at the same time as structural transformation is "creating a large, growing, and politically influential group of net food consumers whose real incomes are compromised when food prices rise" 
(Nguyen and Talbot 2014: 319). Hence Nguyen et al. (2017: 4) argue that "rice policy formulation, which involves the Party's top leadership, is critical to the Party's political survival, and underpins Vietnam's development story in the past, and likely in the future." They maintain that the "tension between socialist policy legacies and more recently introduced objectives of trade liberalisation" affects the formulation of rice policy (Nguyen et al. 2017: 4). ${ }^{11}$ This is despite the fact that, by the mid-2010s, rice contributed only $7 \%$ of GDP and $2 \%$ of exports.

Control over rice prices is mainly exercised through the Vietnam Food Association (VFA), established in 1989 to guide and administer imports and exports. The VFA comprises food producing, processing, and trading enterprises, mostly state-owned, including Vinafood 2, the large stateowned corporation that dominates the rice trade in the Delta. VFA operates under an inter-ministerial committee comprising the Ministry of Trade (MOT), the Ministry of Agriculture and Rural Development (MARD), the Ministry of Finance (MOF), and other agencies, reporting directly to the Prime Minister (Nguyen et al. 2017: 27). Essentially, when prices are low, the government provides state-owned enterprises such as Vinafood 2 with funds to buy and store rice, putting upward pressure on farm-gate prices. When world prices are high, export quotas (now targets) implemented by VFA effectively reduce domestic prices, harming rice producers (and exporters) while benefiting net rice consumers (Nguyen and Talbot 2014: 330). Thus, rice policies have been "motivated in turn by a desire to cater to the competing demands of distinct domestic constituencies of net-producers and net-consumers" (Nguyen and Talbot 2014: 329).

With respect to the first mechanism-supporting farm-gate prices-the government issued a resolution in 2010 that farmers are to be paid a paddy price sufficient to give them a minimum return of $30 \%$ over production costs (Tran and Dinh 2015). MOF determines the floor price or "directed paddy price" based on estimates of production costs provided by provincial People's Committees in consultation with MARD, which has prime responsibility to ensure that the market price is no lower than the directed price. In a 2011 circular, a floor price for rice exports was introduced, with the MOF and VFA primarily responsible. Meanwhile, the government has invested in vastly expanding storage capacity in the Delta to allow for the accumulation of buffer stocks to support these prices. However, it has proved difficult to calculate production costs in order to set the paddy price. The floor price may not account for costs such as family labour, interest, rental, or transport to the point of sale, and in any case will vary 
from location to location (Tran and Dinh 2015). Moreover, the VFA and its constituent enterprises are not directly involved in buying paddy from farmers, which is almost entirely in the hands of numerous primary collectors who operate with small margins. Hence, as argued in Chap. 18, it may be infeasible to enforce this policy. Nguyen (2013) reports that with the floor price of VND $4000 / \mathrm{kg}$ for the summer-autumn crop of 2010, farmers' average return over cost was between $19 \%$ and $24 \%$, depending on the quality of seed, well below the targeted $30 \%$. Moreover, as noted above, even though farmers in An Giang averaged a return of 33\% over three seasons in 2009-2010, the net income from rice alone left households below the poverty line.

The more effective instrument for influencing domestic paddy and rice prices in Vietnam has been controlling exports; domestic prices directly reflect the manipulation of export quantities and prices (Nguyen and Talbot 2014). Unlike in Thailand, where the export market is relatively unregulated (though directly impacted by the paddy pledging scheme), the government in Vietnam has, since 1990, sought to "ensure strict control of rice exports at the central level" (Nguyen et al. 2017: 24). Initially, only state-owned companies could export rice because they were easier to control. Up to 2000 , exports were controlled by quotas issued by VFA, most of which were issued to Vinafood 2 and its subsidiaries. Over time, the major rice-producing provinces in the Delta exerted their power to obtain a larger share to allocate to their own state-owned enterprises. However, in 2000, Vinafood 2 was given a monopoly of government-togovernment contracts, which accounted for 50-60\% of exports. From 2001, quotas were removed but replaced with annual export targets. VFA approved contracts up to the target, again favouring Vinafood 2. According to Nguyen et al. (2017: 37), "vested interests are evident in the way VFA manages the rice exports market." For example, the chairman of VFA from 2006 to 2014 was also the general director of Vinafood 2 for much of this period.

In the 2007-2008 global food crisis, VFA pushed for an export ban, which turned out to be in the interests of large companies such as Vinafood 2 rather than producers or consumers (Nguyen et al. 2017: 34). The ban resulted in lower farm prices and higher consumer prices due to hoarding by consumers and wholesalers. Though consumer prices were not as high as they would have been without the ban, poor consumers suffered hardship, while small and large rice producers who had a bumper crop were deprived of a windfall profit. However, large exporters were able to benefit 
by buying rice cheaply and stockpiling until exports recommenced, thus "export companies made bonanza profits while farmers lost out" (Smith 2013: 5).

A decree in 2010 reinforced the control over exports exerted by large enterprises such as Vinafood 2 by requiring exporting firms to meet the minimum requirements of owning a storage capacity of at least $5000 \mathrm{t}$ and a rice mill capable of processing at least $10 \mathrm{t} / \mathrm{hr}$ (Tran and Dinh 2015). However, under pressure from smaller private and state-owned enterprises who were thus pushed out of the export market, these requirements were removed in 2018 , along with a requirement for certification for exporters of organic rice and other specialised types. ${ }^{12}$ This was expected to increase competition and expand exports, particularly of high-quality rice. At the same time, various decrees and circulars have been issued in the 2010s to encourage export firms to invest more in rice-growing provinces and engage directly in supporting farmers (Tran and Dinh 2015). As discussed above, the growth in demand for high-quality and specialised rice is increasing the incentives for downstream actors to reach back in the value chain and integrate with producers, rather than merely aim to buy lowquality rice from traders at the lowest price with no concern about farmers. It remains to be seen how rice price policy will be implemented in this new, more competitive phase.

\section{Rice Price Policy in Cambodia and Laos}

Cambodia and Laos do not have the same capacity to move prices that have been demonstrated by Thailand and Vietnam, lacking the resources to enter the market on a scale sufficient to boost farm-gate prices and lacking full control over cross-border trade in paddy and rice. Prices in Cambodia and Laos largely reflect prices in their higher-producing, higher-income neighbours. Nevertheless, the same internal political dynamic is evident, with commercial paddy producers agitating for higher prices, millers, and exporters lobbying for support, and government agencies pursuing sometimes conflicting agendas.

This is seen most clearly in Cambodia. At the time of the food price crisis in 2007-2008, Cambodia temporarily banned exports but the ban was not effective, given the informal cross-border trade in paddy to Vietnam, and in any case it was soon lifted (Dawe and Slayton 2010). Domestic prices rose sharply, affecting many poor households who were net consumers of rice. More recently, the rapid expansion of production 
and exports has led to the problem of low farm returns, notwithstanding the government's promise of "white gold"- a sharp fall in paddy prices in 2016 prompted farmers in Battambang Province, one of the main producers of export-quality rice, to stage public protests, symbolically pouring rice onto National Road 5 (Kali and Cheng 2016), braving the oftenviolent state response to protest under the Hun Sen regime (Strangio 2014). The farmers complained that traders were offering lower prices or not buying paddy at all, whereas they had incurred large debts to microfinance institutions for fertilisers, pesticides, and farm machinery (see Chap. 15) and could not afford to store their paddy and wait for higher prices. The traders in turn were responding to reduced demand from millers, who had insufficient working capital to purchase and store paddy and were buying only to fill export orders (see Chap. 16).

Earlier in 2016, the Cambodia Rice Federation (CRF), the peak body of rice millers and exporters headed by Hun Sen's wealthy and influential son-in-law, Sok Puthyvuth, had lobbied the government for concessional loans to enable the purchase of paddy from farmers, as well as action to prevent what it described as illegal imports of rice from Vietnam that were undermining domestic prices (Kang 2016). The Ministry of Commerce agreed to USD 27 million in "emergency loans" to millers. The government-owned Rural Development Bank (RDB), charged with issuing the loans, stated that millers would be offered loans at $8 \%$ on condition that they purchased paddy from farmers for no less than USD $218 / \mathrm{t}$, said to be a price that "ensures farmers make a profit on their crop" (Hor 2016). The government's decision to disburse loans directly through the RDB pointedly sidestepped the CRF. A Bank official criticised millers, claiming many sought funding to increase their machinery and storage facilities rather than to purchase paddy, adding that the Bank would take measures to ensure that the loans were not abused by millers seeking to purchase "motorbikes, cars or land" (Kang 2016). Nevertheless, the CRF was ultimately involved in administering the emergency loans to its members.

Again in 2018, falling prices prompted the Ministry of Commerce to consult with local authorities, the $\mathrm{RDB}$, rice millers, and rice exporters to "put an end to the price fall and ensure farmers' livelihoods" (Sum 2018). The problem was again attributed to "a lack of capital from rice millers and exporters to buy rice, and a decline in the price of rice in the international market." The Ministry was considering "disbursing loans to rice millers and exporters so that they can purchase white rice by taking rice as 
collateral" (Sum 2018), though the CRF complained that the problem was the lack of stocks in the first place.

The CRF has also proposed a "consortium" of large millers and exporters to manage the export price by regulating supply, arguing that "if exporters get a good price, rice millers and farmers will benefit too as it will allow them to sell at higher prices... Currently, our members compete against each other when foreign buyers come to buy our rice, which forces prices to fall" (Kang 2016). This proposal added weight to the concerns of some policy observers that "instead of developing new products and markets, Cambodia's so-called rice barons will use their power and influence to limit competition. This would mean a return to the large, undifferentiating paddies of Angkor, missing a valuable opportunity to capitalise on Cambodia's unique strengths" (EIU 2014). However, the Ministry of Commerce was understandably sceptical about the feasibility of such a cartel, given Cambodia's relatively small share of rice exports and the increasingly competitive nature of the international market. This competition will be accentuated if Cambodia loses its preferential access to EU and US markets, as now seems likely (EIU 2019). ${ }^{13}$ The recurrent problem of low farm-gate prices also raises doubts about whether higher export prices, if they could be achieved, would in fact be passed back to farmers. The self-interested behaviour of CRF members was highlighted in a recent internal report (Boyle and Sopheakpanha 2018).

In Laos, as in Vietnam, "the party legitimates its economic reforms using a wider socialist ideology, [while] socialist ideology defines the framework of reforms... [Hence] the party is still trying to bring the economy under state control and to maintain its political control" (Yamada 2018: 17). This is seen in the long-standing practice of setting targets for area, yield, and production throughout the country that farmers are urged to fulfil as though they were still in a collective economy (though, as noted above, the attention has now been concentrated on more productive "focal areas"). With regard to price, the National Rice Policy issued in 2016 declares that the "rice price will be stabilized and managed against fluctuation in order to provide $30 \%$ of profit margin. The Government will intervene pricing in accordance with global market price mechanism of rice." ${ }^{14}$ The Policy also promises a $5-10 \%$ increase in market price for farmers certified for "clean agricultural practices" for three years.

As noted in Chap. 9, the State Food Enterprise (SFE) has been a player in the domestic market, buying rice at a controlled price and holding rice stocks. However, the state's capacity to control domestic rice prices is lim- 
ited. Eliste and Santos (2012: 50-54) found that the price of rice in Laos closely follows the price of glutinous rice in Thailand, which produces twice as much glutinous rice as Laos. The informal cross-border trade ensures that glutinous rice prices in the two countries are brought into line (though not with Thai white and jasmine rice, the prices of which are determined by export demand). Thus, price policy in Thailand may have more influence on rice prices in Laos than any intervention by the government of Laos. This probably means that Lao farmers benefited in the early 2010s from the high prices induced by the paddy pledging scheme in Thailand and have suffered since the mid-2010s from the overhang of the large stockpile that resulted.

The imposition of quotas and ad hoc bans on trade in paddy and rice at the provincial and national levels, designed to keep consumer prices low, has in the past harmed farmers and millers and damaged prospects for a profitable export industry (Chap. 9). Indeed, Eliste and Santos (2012) calculated that the effect of trade policy in the 2000s was a net transfer from producers to consumers, which more than offset the implicit subsidy of government programmes to support rice farmers. That is, there was a net tax on rice farmers, placing Laos at an earlier stage than Thailand in Anderson and Hayami's (2019) transition from taxation to protection of agriculture. There is no mention of the use of trade measures to stabilise domestic prices in the 2016 policy statement (nor of any other specific price measures for that matter), but with the increasing size of the exportable surplus and government support to increase milling capacity and sign export contracts, especially with China, discretionary bans seem less likely. As Eliste and Santos (2012) argue, given that 75\% of urban households spend less than $30 \%$ of their budget on rice, it is more efficient to maintain a small food reserve as a safety net than to continually intervene in an attempt to stabilise the retail price.

\section{Concluding Remarks}

The Lower Mekong Basin has long provided a range of suitable environments for subsistence rice farming, from the narrow inland valleys of the Northern Highlands, to the rainfed lowland plains of the Khorat Plateau, to the extensive floodplain of the Tonle Sap Basin and the Delta. Indeed, rice was "the only food staple that could be grown intensively in [this] monsoon-driven agro-climatic environment" (Timmer 2013: 83). Hence, rice has long dominated production and consumption, more so than with 
other staples in other regions of the world. Moreover, the Basin has a long history of centralised political control based on intensive rice cultivationfrom Scott's (2010) "paddy states," of which Angkor was the epitome, to the modern nation-states that now share the region. The intensification of smallholder rice farming and the stabilisation of rice supplies and prices has been critical to the political legitimacy and survival of these states.

Given the special place of rice in both the agro-ecology and the political economy of the Basin, there has been a deep-seated desire to control access to resources, the activities of farmers, and the appropriation of value along the supply chain. Thus, despite the declining share of rice in both the incomes of rural households and the expenditure of urban households, as well as its declining importance to government budgets and national economies, "rice growing has been kept profitable through subsidies, virtually free irrigation water, price support and stabilization programs, and welldeveloped rural infrastructure that ensured low marketing margins for rice" (Timmer 2008: 4). This may not be the best set of policies to ensure rural prosperity and food security for the Mekong countries in the coming decades. Timmer (2008: 4) argues that the way forward "is to make rice less 'different' to consumers, farmers, and the world market by making it more of an economic commodity and less of a political commodity."

There has been significant progress in this direction, as evidenced by a gradual relaxation of targets and controls, more diversified and profitable rural economies, greater integration with modern supply chains, a better educated and more mobile rural population, and moves towards coordinated international efforts to stabilise the world rice market. However, the "white gold" of the Mekong is likely to be the subject of policy contention for some time yet.

\section{Notes}

1. Smith (2013) reports that in Dong Thap Province, the area of paddy land covered by the "large field" programme increased from 1467 ha in 2010 to 21,218 ha in the main (winter-spring) season of 2013 , equivalent to $10 \%$ of the area planted. The programme involved 11,205 households. Of the total area in the programme, 16,148 ha were covered by written contracts between companies and farmer groups, of which contracts with the An Giang Plant Protection Company covered 5070 ha.

2. See a report from the Medium-Term Cooperation Programme with Farmers' Organisations in Asia and the Pacific Phase Two (MTCP2) on 
"Promoting partnership of smallholder rice producer group and a rice company." Available at http://www.asiapacificfarmersforum.net/laospromoting-partnership-of-small-holder-rice-producer-group-and-a-ricecompany/ (viewed 23 July 2019).

3. Estimate by Alan Potkin in message to Laofab Group, 24 July 2019.

4. The impact on fisheries is more complex but likely to be severe (Hecht et al. 2019). Given that many rural households combine rice farming with fishing, the overall impact of dams on rice-based livelihoods is a matter of serious concern.

5. Brian Eyler, Southeast Asia Programme Director for the Stimson Center, commented in an interview: "There's very little that Vietnam domestically can do. The [Mekong] delta, being a very important agricultural production zone for Vietnam, could be managed in a way where more water is stored from the monsoon season into the dry season, and this would be a way to mitigate what's happening upstream." While supportive of Resolution 120 of 2017, which aims to restore the Delta's natural ecosystem properties, Eyler remarks that "Resolution 120 won't work if all these upstream impacts are still coming down to the Mekong delta." (China needs to put its money where its mouth is and actually release some water to relieve the drought, Interview with Brian Eyler on Radio Free Asia, 25 July 2019. Available at https://www.rfa.org/english/news/vietnam/brian-eyler-mekongdrought-07252019170305.html?utm, viewed 5 August 2019.)

6. See Government of Lao PDR, National Rice Policy for Food Security, Section 2.2 (issued in June 2016).

7. Shu Fukai, personal communication, l May 2019.

8. The official zoning of land into "suitable" and "unsuitable" for rice farming can be viewed online at the following site-http://agri-map-online. moac.go.th/ (viewed 3 July 2019).

9. This includes encouragement to reduce the area of the second rice crop in favour of cash crops, green manure, or leaving the land idle.

10. This despite the fact that the benefits were heavily skewed in favour of large farms (Poapongsakorn 2010) and that rural households in the Northeast derived most of their income from non-farm sources (Rambo 2017).

11. According to Nguyen et al. (2017: 4), this accounts for the "stickiness of policy-making institutions."

12. See Vietnam News, New decree removes barriers for rice exporters, 1 September 2018. Available at https://vietnamnews.vn/economy/ 464972/new-decree-removes-barriers-for-rice-exporters.html\#l cqDtu WtjHlKeZu3.97 (viewed l August 2019).

13. One of the issues with Cambodia's preferential access to the EU market is the alleged rebadging of rice imported from Vietnam as Cambodian rice.

14. Government of Lao PDR, National Rice Policy for Food Security, Section 23.6, issued in June 2016. 


\section{REFERENCES}

Anderson, K., and Hayami, Y., 2019. The political economy of agricultural protection: East Asia in international perspective. In K. Anderson, ed., Asia-Pacific Trade Policies Vol. 1: Political Economy of Agricultural Protection in East Asia, chap. 2. New Jersey: World Scientific.

Biggs, D., Miller, F., Chu, T. H., and Molle, F., 2009. The delta machine: water management in the Vietnamese Mekong Delta in historical and contemporary perspectives. In François Molle, Tira Foran, Mira Kakonen, eds., Contested Waterscapes in the Mekong Region: Hydropower, Livelihoods and Governance, pp. 203-225. London: Earthscan.

Blake, D. J. H., 2019. Damming Isan's last free-flowing river for cash. Bangkok Post, 25 July 2019. Available at https://www.bangkokpost.com/opinion/ opinion/1718439/damming-isans-last-free-flowing-river-for-cash (viewed 31 July 2019).

Blake, D. J. H., and Barney, K., 2018. Structural injustice, slow violence? The political ecology of a 'best practice' hydropower dam in Lao PDR. Journal of Contemporary Asia 48: 808-834.

Boyle, D., and Sopheakpanha Nem, 2018. Cambodian rice body faces own shortcomings. VOA News, 19 February 2018. Available at https://www.voanews. com/east-asia-pacific/cambodian-rice-body-faces-own-shortcomings (viewed 5 August 2019).

Bui, C. B., and Nguyen, T. L., 2017. New rice varieties adapted to climate change in the Mekong River Delta of Vietnam. Vietnam Journal of Science, Technology and Engineering 60: 30-33.

Cazzuffi, C., McKay, A., and Perge, E., 2018. The Impact of Commercialization of Rice on Household Welfare in Rural Viet Nam. WIDER Working Paper 2018/130. Helsinki: United Nations University World Institute for Development Economics Research.

Chapman, A., and Van, P. D. T., 2018. Climate change is triggering a migrant crisis in Vietnam. The Conversation, 9 January 2018. Available at https://theconversation.com/climate-change-is-triggering-a-migrant-crisis-in-vietnam-88791 (viewed 31 July 2019).

Chuasuwan, C., 2018. Rice Industry Outlook, 2018-2020. Bangkok: Krungsiri Research.

Clément, C., Vinckevleugel, J., Pavelic, P., Xiong, K., Valee, L., Sotoukee, T., Shivakoti, B. R., and Vongsathien, K., 2018. Community-Managed Groundwater Irrigation on the Vientiane Plain of Lao PDR: Planning, Implementation and Findings from a Pilot Trial. IWMI Working Paper 183. Colombo: International Water Management Institute (IWMI).

Cosslett, T. L., and Cosslett, P. D., 2018. Sustainable Development of Rice and Water Resources in Mainland Southeast Asia and Mekong River Basin. Singapore: Springer Nature. 
Cramb, R. A., and Newby, J. C., 2015. Trajectories of rice-farming households in Mainland Southeast Asia. In R.A. Cramb, ed., Trajectories of Rice-Based Farming Systems in Mainland Southeast Asia, pp. 35-72. Canberra: Australian Centre for International Agricultural Research.

Dawe, D., and Slayton, T., 2010. The world rice market crisis of 2007-2008. In David Dawe, ed. The Rice Crisis: Markets, Policies and Food Security, pp. 15-28. London and Washington, DC: Food and Agriculture Organization of the United Nations and Earthscan.

Demont, M., and Rutsaert, P., 2017. Restructuring the Vietnamese rice sector: towards increasing sustainability. Sustainability 9: 325.

EIU, 2014. Selling "white gold”: Cambodia's rice exports. Economist Intelligence Unit: Cambodia, 11 July 2014. Available at http://country.eiu.com/article. aspx?articleid $=642005848$ (viewed 5 August 2019).

EIU, 2019. Burning bridges. Economist Intelligence Unit: Cambodia, 25 June 2019. Available at http://country.eiu.com/article aspx?articleid=112815709 6\&Country=Cambodia\&topic=Economy (viewed 5 August 2019).

Eliste, P., and Santos, N., 2012. Lao People's Democratic Republic Rice Policy Study 2012. Rome: Food and Agriculture Organization (FAO).

FAO, 2018. Thailand: Country Fact Sheet on Food and Agriculture Policy Trends. Rome: Food and Agriculture Policy Decision Analysis Team, Food and Agriculture Organization of the United Nations.

Friend, R. M., et al., 2019. Agricultural and food systems in the Mekong region: drivers of transformation and pathways of change. Emerald Open Research 1: 12.

Grandstaff, T. B., Grandstaff, S., Limpinuntana, V., and Suphanchaimat, N., 2008. Rainfed revolution in Northeast Thailand. Southeast Asian Studies 46: 289-376.

Hecht, J. S., Lacombe, G., Arias, M. E., Thanh, D. D., and Piman, T., 2019. Hydropower dams on the Mekong River basin: a review of their hydrological impacts. Journal of Hydrology 568: 285-300.

Hoanh, Chu Thai, Facon, Thierry, Try Thuon, Bastakoti, R. C., Molle, F., and Phengphaengsy, G., 2009. Irrigation in the Lower Mekong Basin countries: the beginning of a new era? In François Molle, Tira Foran, Mira Kakonen, eds., Contested Waterscapes in the Mekong Region: Hydropower, Livelihoods and Governance, pp. 143-171. London: Earthscan.

Hor Kimsay, 2016. Terms announced on rice lending package. Phnom Penh Post, 20 September 2016. Available at https://www.phnompenhpost.com/business/terms-announced-rice-lending-package (viewed 5 August 2019).

IFC, 2015. Cambodia Rice: Export Potential and Strategies. Cambodia Agribusiness Series No. 4. Phnom Penh: International Finance Corporation.

IFC, 2017. Nam Ou River Basin Profile Summary Document: Environmental and Social Characteristics of a Key River Basin in Lao PDR. Washington, DC: International Finance Corporation.

Johnston, R., Roberts, M., Try, T., and de Silva, S., 2013. Groundwater for Irrigation in Cambodia. Issue Brief. Colombo: International Water Management Institute. 
Kali Kotoski, and Cheng Sokhorng, 2016. No sign of relief for rice industry. Phnom Penh Post, 15 September 2016. Available at https://www.phnompenhpost.com/business/no-sign-relief-rice-industry (viewed 5 August 2019).

Kang Sothear, 2016. Federation mulls supporting rice export price. The Cambodia Daily, 18 March 2016. Available at https://www.cambodiadaily.com/business/ federation-mulls-supporting-rice-export-price-110081/(viewed 5 August 2019).

Mellor, J. W., 2017. Agricultural Development and Economic Transformation: Promoting Growth with Poverty Reduction. Cham, Switzerland: Palgrave Macmillan.

Molle, F., Shah, T., and Barker, R., 2003. The Groundswell of Pumps: Multilevel Impacts of a Silent Revolution. Paper prepared for ICID-Asia Meeting, Taiwan, November 2003.

Molle, F., Floch, P., Promphakping, B., and Blake, D. J. H., 2009. The 'greening of Isaan': politics, ideology and irrigation development in the northeast of Thailand. In F. Molle, T. Foran, and M. Kakonen, eds., Contested Waterscapes in the Mekong Region: Hydropower, Livelihoods and Governance, pp. 253-282. London: Earthscan.

MRC, 2017. The effects of Chinese dams on water flows in the Lower Mekong Basin. Mekong River Commission News, 6 June 2017. Available at http://www. mrcmekong.org/news-and-events/news/the-effects-of-chinese-dams-onwater-flows-in-the-lower-mekong-basin/ (viewed 29 July 2019).

Nguyen, H. T. M., Do, H., Kay, A., Kompas, T., Nguyen, C. N., and Tran, C. T., 2017. The Political Economy of Rice Exceptionalism during Economic Transition: The Case of Rice Policy in Vietnam. Crawford School Working Paper No. 1713. Canberra: Crawford School of Public Policy, Australian National University.

Nguyen Manh Hai, and Talbot, T., 2014. The political economy of food price policy in Vietnam. In P. Pinstrup-Andersen, ed., Food Price Policy in an Era of Market Instability: A Political Economy Analysis, pp. 319-338. Oxford: Oxford University Press.

Nguyen Ngoc Mai, and Dao The Anh, 2018. A Review of Vietnam's Recent Agricultural Policies. FFTC Agricultural Policy Platform. Taipei: Food and Fertilizer Technology Centre. Available at http://ap.fftc.agnet.org/ap_db. php?id=908 (viewed 30 July 2019).

Nguyen Trung Kien, 2013. Food Security in Vietnam: Situation and Policy Options. Paper presented at Regional Dialogue on Meeting Food Security Goals with Good Policy, 26-27 June 2013, Medan, Indonesia.

Noble, A., and Hoanh, C. T., n.d. Irrigation expansion or other opportunities for sustainable agriculture development-lessons learned from MRB. Vientiane: International Water Management Institute.

Paarlberg, D., and Paarlberg, P., 2000. The Agricultural Revolution of the 20th Century. Ames: Iowa State University Press.

Poapongsakorn, N., 2010. The political economy of Thai rice price and export policies in 2007-2008. In David Dawe, ed. The Rice Crisis: Markets, Policies 
and Food Security, pp. 191-217. London and Washington, DC: Food and Agriculture Organization of the United Nations and Earthscan.

Pongsrihadulchai, A., 2018. Thailand's Rice Industry and Current Policies towards High Value Rice Products. Paper submitted for International Seminar on Promoting Rice Farmers' Market Through Value-Adding Activities, 6-7 June 2018, Kasetsart University, Bangkok.

Promkhambut, A., and Rambo, A. T., 2017. Multiple cropping after the rice harvest in rainfed rice cropping systems in Khon Kaen Province, Northeast Thailand. Southeast Asian Studies 6: 325-338.

Rambo, A. T., 2017. The agrarian transformation in Northeastern Thailand: a review of recent research. Southeast Asian Studies 6: 211-245.

Ricks, J., 2018. Politics and the price of rice in Thailand: public choice, institutional change and rural subsidies. Journal of Contemporary Asia 48: 395-418.

Rigg, J., Salamanca, A., and Thompson, E. C., 2016. The puzzle of East and Southeast Asia's persistent smallholder. Journal of Rural Studies 43: 118-133.

SCB Economic Intelligence Centre, 2017. Thai organic foods have healthy growth potential. Bangkok Post, 6 February 2017.

Scott, J. C., 2010. The Art of Not Being Governed: An Anarchist History of Upland Southeast Asia. Singapore: NUS Press.

Smith, W., 2013. Agriculture in the Central Mekong Delta: Opportunities for Donor Business Engagement. London: Overseas Development Institute.

Strangio, S., 2014. Hun Sun's Cambodia. New Haven: Yale University Press.

Sum Manet, 2018. Commerce Ministry intervenes to stop fall in rice price. Khmer Times, 19 July 2018. Available at https://www.khmertimeskh.com/513263/ commerce-ministry-intervenes-to-stop-fall-in-rice-price/(viewed 6 August 2019).

Sunsuk, D., 2016. Isaan farmers and local officials slam failed rice policy. The Isaan Record, 25 October 2016.

Timmer, C. P., 2008. Poverty in Asia and the Transition to High-Priced Food Staples. Reducing Poverty and Hunger in Asia Brief 2. Washington, DC: International Food Policy Research Institute.

Timmer, C. P., 2013. Food security in Asia and the Pacific: the rapidly changing role of rice. Asia and the Pacific Policy Studies 1: 73-90.

Timmer, C. P., 2015. The dynamics of agricultural development and food security in Southeast Asia: historical continuity and rapid change. In Ian Coxhead, ed., Routledge Handbook of Southeast Asian Economics, pp. 89-113. London and New York: Routledge.

Tobias, A., Molina, I., Valera, H. G., Abdul Mottaleb, K., and Mohanty, S., 2012. Handbook on Rice Policy for Asia. Los Banos: International Rice Research Institute.

Tran Cong Thang and Dinh Thi Bao Linh, 2015. Rice Policy Review in Vietnam. FFTC Agricultural Policy Platform. Taipei: Food and Fertilizer Technology Centre. Available at http://ap.fftc.agnet.org/ap_db.php?id=406 (viewed 30 July 2019). 
Vote, C., Eberbach, P., Inthavong, T., Lampayane, R. M., Vongthilard, S., and Wade, L. J., 2019. Quantification of an overlooked water resource in the tropical rainfed lowlands using RapidEye satellite data: a case of farm ponds and the potential gross value for smallholder production in southern Laos. Agricultural Water Management 212: 111-118.

Warr, P., 2015. Agricultural growth and rural poverty reduction in Mainland Southeast Asia. In Rob Cramb, ed., Trajectories of Rice-Based Farming Systems in Mainland Southeast Asia, pp. 17-34. Canberra: Australian Centre for International Agricultural Research.

Watanabe, K., 2017. Improvement in rainfed rice production during an era of rapid national economic growth: a case study of a village in Northeast Thailand. Southeast Asian Studies 6: 293-306.

Welcher, P., 2017. Thailand: Rice Market and Policy Changes over the Past Decade. GAIN Report No. TH7011. Global Agricultural Information Network, United States Department of Agriculture Foreign Agricultural Service.

World Bank, 2015. Cambodian Agriculture in Transition: Opportunities and Risks. Economic and Sector Work, Report No. 96308-KH. Washington, DC: World Bank.

Yamada, N., 2018. Legitimation of the Lao People's Revolutionary Party: Socialism, Chintanakan Mai (New Thinking) and reform. Journal of Contemporary Asia 48: 717-738.

Open Access This chapter is licensed under the terms of the Creative Commons Attribution 4.0 International License (http://creativecommons.org/licenses/ by $/ 4.0 /$ ), which permits use, sharing, adaptation, distribution and reproduction in any medium or format, as long as you give appropriate credit to the original author(s) and the source, provide a link to the Creative Commons licence and indicate if changes were made.

The images or other third party material in this chapter are included in the chapter's Creative Commons licence, unless indicated otherwise in a credit line to the material. If material is not included in the chapter's Creative Commons licence and your intended use is not permitted by statutory regulation or exceeds the permitted use, you will need to obtain permission directly from the copyright holder.

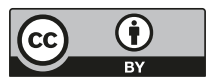

